AGRITECH, Vol. 37, No. 4, November 2017, Hal. 453-461 DOI: http://doi.org/10.22146/agritech.12789 ISSN 0216-0455 (Print), ISSN 2527-3825 (Online) Tersedia online di https://jurnal.ugm.ac.id/agritech/

\title{
Desain dan Uji Kinerja Mesin Pemarut Sagu Tipe TPB 01
}

\author{
Design and Performance Test Sago Grating Machine Type TPB 01 \\ Ahmad Thoriq ${ }^{1 *}$, Agus Sutejo² \\ ${ }^{1}$ Departemen Teknik Pertanian dan Biosistem, Fakultas Teknologi Industri Pertanian, Universitas Padjadjaran, \\ Jl. Raya Bandung Sumedang KM 21, Jatinangor, Sumedang, Jawa Barat, Indonesia 40600 \\ ${ }^{2}$ Departemen Teknik Mesin dan Biosistem, Fakultas Teknologi Pertanian, Institut Pertanian Bogor, \\ Kampus IPB Darmaga, Jl. Lingkar Akademik, Dramaga, Bogor, Jawa Barat, Indonesia 16680 \\ Email: thoriq.unpad@gmail.com
}

Submisi: 24 Agustus 2016; Penerimaan: 28 September 2017

\begin{abstract}
ABSTRAK
Pengolahan sagu yang dilakukan kelompok masyarakat di Pulau Papua hanya menggunakan mesin pemarut. Namun mesin pemarut yang digunakan kurang memperhatikan faktor keamanan pangan karena ada bagian alat yang kontak dengan empulur sagu yang terbuat dari besi yang mudah berkarat. Hal ini tentunya akan mempengaruhi mutu dan kualitas pati sagu yang dihasilkan. Penelitian ini bertujuan untuk melakukan desain dan uji kinerja mesin pemarut sagu dengan mata parut stainless steel. Metode yang digunakan pada penelitian ini yaitu melalui pendekatan rancangan teknik yang terdiri atas indentifikasi masalah, perumusan dan penyempurnaan konsep desain, analisis desain dan gambar teknik, pembuatan mesin, uji fungsional, dan uji kinerja. Hasil penelitian menunjukkan bahwa mesin pemarut sagu hasil rancangan memiliki kapasitas 649,38 kg/jam pada kecepatan putar silinder parut $1400 \mathrm{rpm}$, dan tingkat kehilangan empulur sagu sebesar $6,71 \%$.
\end{abstract}

Kata kunci: Silinder parut; pemarut sagu; Papua; mesin pemarut

\begin{abstract}
Sago processing conducted by the people of Papua have used grater, but it lacks of attention on food safety because one of iron part (corrosion) having contact to the sago. However, it may affect the quality of sago starch. This study aimed to design and to test the performance of machine grater use stainless steel grade eyes. The method used was through the engineering design approach consists of problem identification, formulation and refinement of the design concept, design analysis and work drawing, machinery manufacturing, functional testing and performance testing. The results showed that the designed sago grater machines has a capacity of $649.38 \mathrm{~kg} / \mathrm{h}$ at a speed of $1400 \mathrm{rpm}$ rotary cylinder grate, and the sago pith loss rate of $6.71 \%$.
\end{abstract}

Keywords: Cylinder grated; grater machine; Papua; sago grater 


\section{PENDAHULUAN}

Sagu merupakan tanaman perkebunan yang memiliki keunggulan utama yaitu produktivitasnya tinggi, dapat hidup pada lahan marginal, dan dapat mengkonversi air tanah (Bintoro dkk., 2010). Lebih dari 60\% tanaman sagu yang tumbuh di dunia terdapat di Indonesia dan lebih dari 95\% tanaman tersebut tumbuh di bagian timur khususnya di Papua dan Papua Barat (Bintoro, 2008). Saat ini luas tanaman sagu di Pulau Papua sebesar 3.173.322 hektar (UP4B, 2013). Namun diperkirakan 6 juta ton pati kering tiap tahun terbuang percuma karena tidak sempat dipanen (Bintoro, 2010). Produksi sagu yang rendah ini disebabkan sebagian besar pengolahan sagu oleh masyarakat dilakukan secara tradisional dan hanya dimanfaatkan sebagai bahan pangan pokok.

Penerapan alat dan mesin pengolahan sagu di Pulau Papua masih terbatas pada penggunaan mesin pemarut, terutama di lokasi sagu yang lebih dekat dengan kota (Thoriq dan Herodian, 2015). Mesin pemarut dibuat sendiri oleh masyarakat dengan mata parut paku yang dipasangkan pada kayu menggunakan tenaga penggerak motor bensin 5,5 HP. Sebenarnya terdapat beberapa mesin bantuan dari pemerintah, tetapi mesin tersebut tidak digunakan lagi oleh masyarakat, terbengkalai dan hanya menjadi besi tua. Berdasarkan pengamatan, salah satu mesin diantaranya didesain seperti mesin pencacah sampah dengan mata parut seperti pisau sedangkan mesin yang lain didesain dengan mata parut rantai. Menurut masyarakat mesin-mesin ini tidak ergonomis dan rendemen pati yang dihasilkan rendah (UP4B, 2013). Berdasarkan pengujian, mesin pemarut sagu dengan mata parut tipe jarum meghasilkan rendemen tertinggi sebesar 24,34\%, mata parut tipe gergaji baja menghasilkan rendemen sebesar $21,79 \%$, mata parut tipe parut chainsaw yang telah dimodifikasi menghasilkan rendemen sebesar 21,10\% dan parut chainsaw yang umum digunakan oleh pengolah sagu menghasilkan rendemen sebesar 19,31\% (Hermanto dkk., 2011).

Petani sagu di Papua lebih menyukai mesin pemarut sagu dengan mata parut berbentuk paku dengan beberapa alasan yaitu waktu pemarutan lebih cepat, proses pembuatan silinder parut lebih mudah, dan rendemen pati yang dihasilkan lebih tinggi (Thoriq dan Herodian, 2015). Modifikasi dilakukan dengan menambahkan hopper dan penutup silinder parut. Mesin pemarut tersebut memiliki kapasitas efektif pemarutan $418 \mathrm{~kg} / \mathrm{jam}$, rendemen pati 38,09\% dan kadar pati yang terikut ke ampas 4\% (Darma, 2011). Di sisi lain, mesin pemarut sagu hasil rancangan masyarakat maupun hasil penelitian yang terdapat di Papua kurang memperhatikan faktor keamanan pangan. Salah satunya adalah masih adanya bagian alat yang terbuat dari besi (mudah berkarat) yang dapat kontak langsung dengan sagu. Kondisi ini akan mempengaruhi mutu dan kualitas pati sagu yang dihasilkan karena adanya proses oksidasi antara empulur sagu dan mata parut sagu. Oleh karena itu penelitian ini bertujuan melakukan rancang bangun dan uji kinerja mesin pemarut sagu dengan mata parut bergigi menggunakan konstruksi stainless steel (ss).

\section{METODE PENELITIAN}

Bahan yang digunakan untuk pembuatan konstruksi mesin terdiri atas poros as Ǿ $30 \mathrm{~mm}, 65 \mathrm{~cm}$, silinder Ǿ $17 \mathrm{~mm}$, $40 \mathrm{~cm}$, kawat las SS 304, plat SS 304, tebal $2 \mathrm{~mm}$, hollow SS, $4 \times 4 \mathrm{~cm}$, sabuk V tipe B65, puli Ǿ $15 \mathrm{~cm}$, puli $\varnothing 7,20 \mathrm{~cm}$, motor bensin (5,5 HP), mur dan baut SS, bearing UCP 207, batu gurinda. Peralatan yang digunakan untuk pembuatan kontruksi mesin terdiri atas las argon, gurinda tangan, mesin bubut, mesin bor, meteran, kunci-kunci, pemotong plat dan bahan dan peralatan yang digunakan untuk pengujian mesin terdiri atas bongkahan batang sagu, stop watch, tachometer, timbangan digital, plastik dan karung, ember penampung hasil parutan, saringan dan, alat tulis kantor.

Metode yang digunakan pada penelitian ini adalah melalui pendekatan rancangan teknik yang secara lebih rinci dapat dilihat pada Gambar 1.

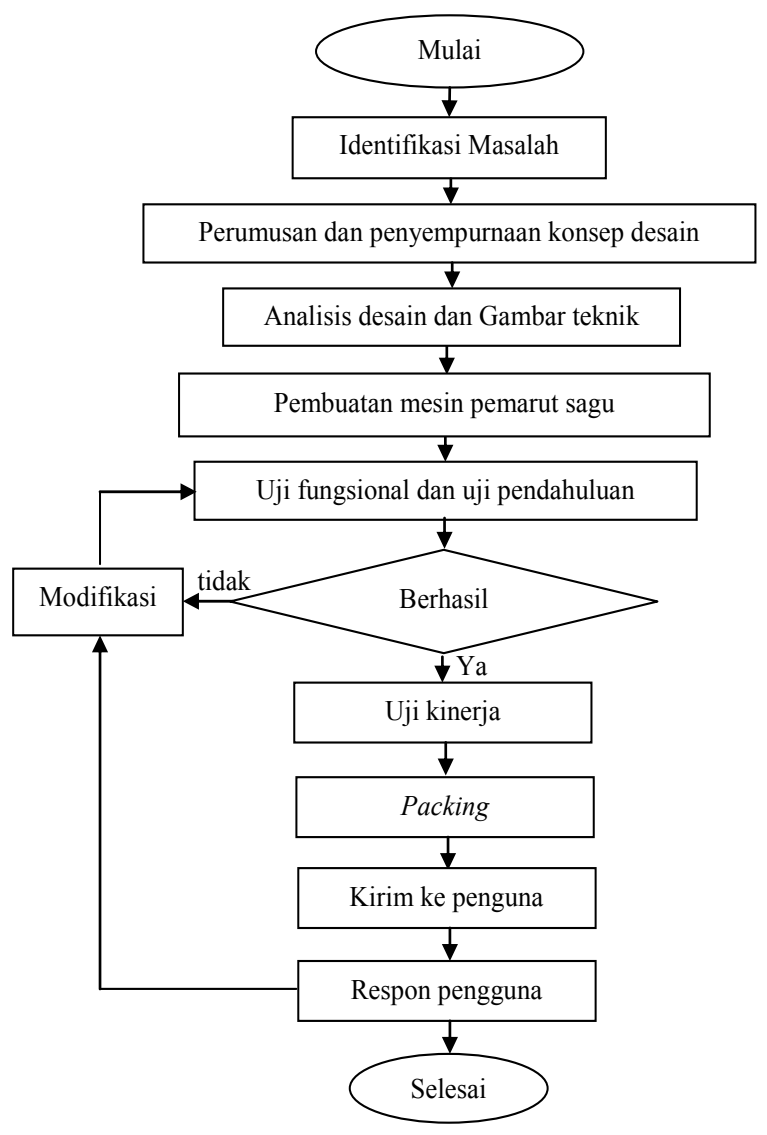

Gambar 1. Diagram alir tahapan penelitian 


\section{Identifikasi Masalah}

Identifikasi masalah yang dilakukan melalui pengamatan langsung dan studi literatur terhadap mesin pemarut sagu yang telah dibuat dan diteliti. Kemudian dilakukan analisis untuk mencari solusi dari permasalahan yang ada. Berdasarkan analisis permasalahan mesin pemarut sagu teridentifikasi sebagai berikut: ada bagian alat terbuat dari besi yang memiliki kontak langsung dengan produk (sagu), kapasitas rendah, mesin dengan mata parut paku lebih disukai masyarakat dibandingkan dengan mata parut jarum, gergaji baja, rantai dan chainsaw. Desain mesin pemarut sagu pada penelitian ini difokuskan pada peningkatan kapasitas dan pembuatan konstruksi mesin menggunakan bahan stainless steel.

\section{Analisis Desain}

Analisis desain mesin pemarut sagu meliputi kreteria rancangan, rancangan fungsional dan rancangan struktural dari tiap komponen pembentuk mesin.

\section{Kriteria Rancangan}

Mesin pemarut sagu hasil penelitian ini selanjutnya langsung digunakan oleh masyarakat pengolah sagu di Kabupaten Teluk Bintuni, Papua Barat. Adapun kriteria rancangan dari mesin pemarut sagu sesuai dengan permintaan dari pengguna diantaranya: (1) menggunakan mata parut tipe paku namun terbuat dari bahan stainless steel; (2) seluruh konsturksi seperti hopper, rangkas, dan silinder parut terbuat dari bahan stainless steel; (3) bagian pemasukan (hopper) dan rangka memiliki tinggi sesuai dengan antropometri ratarata orang Papua; (4) menggunakan tenaga penggerak motor bensin; dan (5) Hopper didesain menggunakan engsel untuk memudahkan proses pembersihan silinder parut.

\section{Rancangan Fungsional}

Setiap bagian komponen pembentuk mesin pemarut sagu memiliki fungsi masing-masing yang berbeda yang pada akhirnya menjadi satu kesatuan yang saling mengikat.

\section{a) Hopper}

Hopper berfungsi sebagai tempat memasukkan bongkahan batang sagu dan penutup silinder parut. Hopper terletak di bagian samping silinder parut, sehingga bahan yang masuk kedalam hopper akan diteruskan ke silinder parut karena pengaruh putaran silinder parut.

\section{b) Unloading (pengeluaran)}

Sagu hasil parutan akan ditampung oleh unloading dan diteruskan ke dalam tempat penampungan hasil parutan.
Tahapan ini juga berfungsi menahan bahan hasil parutan tidak menyebar dari silinder parut.

c) Silinder pemarut

Silinder parut merupakan komponen utama pada mesin pemarut sagu, berfungsi sebagai pisau potong atau pemarut empulur sagu.

\section{d) Tenaga penggerak}

Tenaga penggerak yang digunakan adalah motor bensin 5,5 HP yang berfungsi untuk memberikan gerak silinder parut melalui sistem transmisi belt dan pulley.

\section{e) Sistem transmisi}

Sistem transmisi mesin pemarut sagu terdiri dari beberapa komponen, diantaranya (1) Poros: berfungsi untuk meneruskan putaran dari poros motor bensin ke poros pisau pemotong; (2) Puli (pulley): berfungsi untuk dudukan sabuk, selain itu ukuran diameter puli yang berbeda dapat memperbesar atau memperkecil kecepatan putaran mesin; (3) Sabuk v-belt: berfungsi untuk menyalurkan putaran puli pada motor bensin ke puli pada poros silinder parut. Panjangnya disesuaikan dengan jarak antar puli yang digunakan. Sabuk yang dipakai tipe B65 karena mudah didapatkan di pasaran dan disesuaikan dengan tipe puli yang digunakan; (4) Bantalan (bearing): befungsi sebagai dudukan poros/ as. Ukuran bearing yang digunakan sesuai dengan ukuran diameter as yang dipakai yaitu $50 \mathrm{~mm}$.

\section{f) Rangka mesin}

Rangka berfungsi sebagai dudukan dari silinder pemarut, motor penggerak, dan komponen pendukung lainnya. Sebagai komponen dasar dan tempat dudukan utama dari mesin, rangka harus kuat menahan beban berat dan getaran dari mesin sewaktu dioperasikan.

\section{Rancangan Struktural}

Secara struktural mesin pencacah dan komponen pembentuknya dapat dilihat pada Gambar 2.

\section{a) Hopper (bagian pemasukan)}

Hopper terbuat dari plat stainless steel $2 \mathrm{~mm}$ dengan ukuran $54 \times 43 \times 20 \mathrm{~cm}$. Pada sisi sebelah kiri merupakan bagian pemasukan bongkahan batang sagu dan terdapat engsel pada sisi sebelah kanan, sehingga hopper dapat diangkat namun masih menempel pada rangka untuk memudahkan proses pembersihan. 


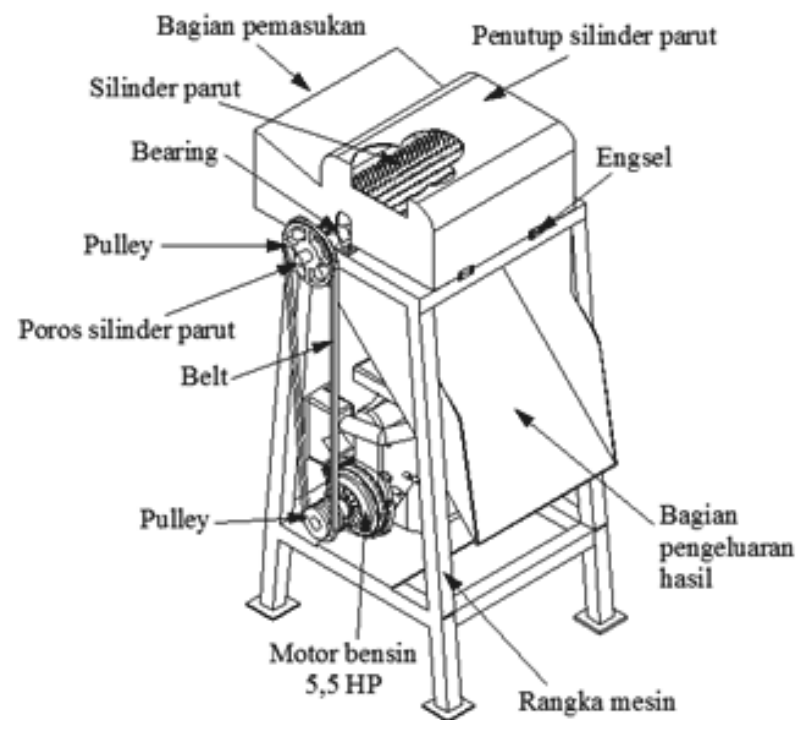

Gambar 2. Desain konstruksi mesin pemarut sagu

\section{b) Unloading (bagian pengeluaran hasil)}

Terbuat dari plat stainless steel yang didesain mengikuti lebar hopper $(43 \mathrm{~cm})$ dan berdasarkan angle of repose dari parutan sagu yaitu pada kemiringan $45^{\circ}$.

\section{c) Silinder pemarut}

Silinder parut merupakan komponen utama mesin pemarut sagu. Silinder parut dan mata parut dibuat dari bahan stainless steel. Pembuatan mata parut mengunakan stainless steel akan berimplikasi pada teknik manufaktur dengan menggunakan las argon dan memerlukan ketelitian tinggi. Hal ini karena mata parut yang berukuran $\varnothing 3 \mathrm{~mm}$ dan panjang 1,5 cm harus di pasangkan pada silinder parut satu per satu menggunakan las argon. Silinder parut dan mata parut memiliki diameter $20 \mathrm{~cm}$, dan panjang $40 \mathrm{~cm}$. Pada bagian tengah silinder parut terdapat poros dengan diameter $30 \mathrm{~mm}$ yang dipasangkan pada bearing UCP 207 dan bearing dipasangkan pada rangka mesin. Pada salah satu sisi poros silinder parut dipasangkan pulley yang terhubung dengan motor penggerak melalui belt. Pemasangan silinder parut pada rangka dan pulley dapat dilihat pada Gambar 3.

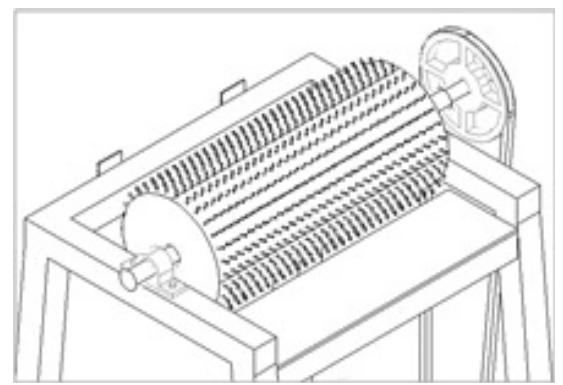

Gambar 3. Pemasangan silinder parut pada rangka dan pulley

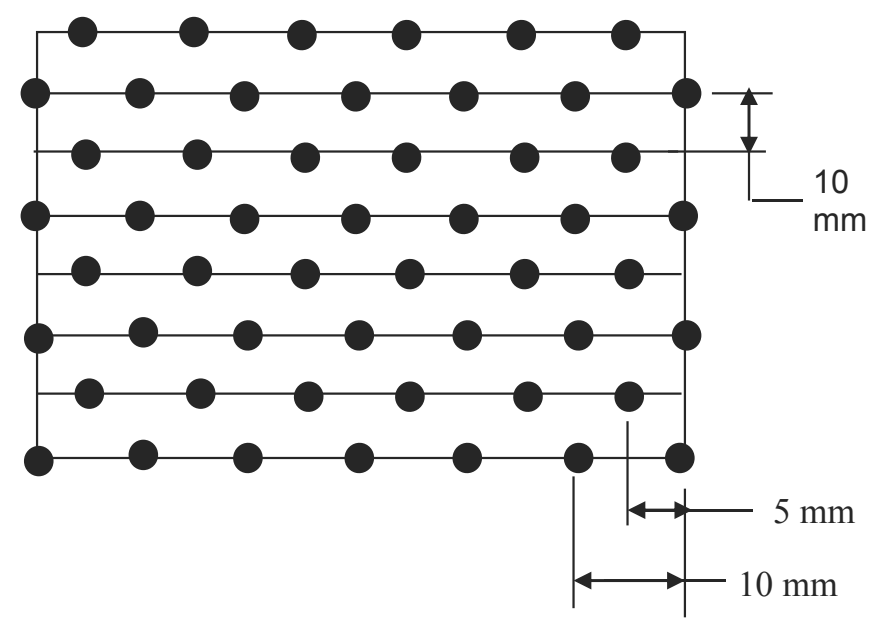

Gambar 4. Bentuk dan susunan mata parut

Mata parut dipasang pada silinder parut dengan posisi tegak lurus serat. Susunan mata parut tidak berpengaruh pada kualitas hasil parutan dan rendemen pati dengan mata parut tegak lurus serat lebih tinggi dibandingkan dengan searah serat (Darma dkk., 2000). Jarak mata parut akan mempengaruhi kapasitas dan rendemen pati yang dihasilkan. Pada jarak mata parut $10 \mathrm{~mm}$ memiliki kapasitas pemarutan lebih besar jika dibandingkan dengan jarak mata parut 6 mm (Payung, 2013). Pada penelitian ini jarak mata parut dalam satu baris yaitu 10 mm dengan susunan mata parut seperti pada Gambar 4.

\section{d) Sistem transmisi}

Motor pengerak akan menggerakkan pulley 1 yang terhubung langsung pada poros motor penggerak dan belt yang tersambung pada pulley 2 yang terhubung langsung pada poros silinder parut. Perbandingan pulley 1 dan pulley 2 adalah $1: 2$. Pulley yang terhubung pada poros motor pengerak memiliki diameter $7,2 \mathrm{~cm}$ dan pulley yang terhubung pada poros silinder parut memiliki diemeter $15 \mathrm{~cm}$. Kedua pulley ini dihubungkan menggunakan belt B65. Silinder parut akan berputar berlawanan jarum jam.

\section{e) Rangka mesin}

Rangka mesin dibuat mengunakan hollow stainless steel $40 \times 40 \times 1,2 \mathrm{~mm}$. Rangka mesin didesain menyesuaikan dengan dimensi silinder parut dan dimensi hopper bagian pemasukan dan pengeluaran. Rangka mesin sebagai tempat dudukan poros silinder dan sejajar dengan bagian pemasukan bongkahan empulur sagu. Tinggi rangka mesin mengacu pada data antropometri pria Papua. Data yang digunakan adalah tinggi siku. Rata-rata tinggi siku pria Papua adalah 103,36 cm (Anonim, 2016), sehingga tinggi rangka mesin maksimum $103,36 \mathrm{~cm}$. Hal ini bertujuan pada proses pemarutan tinggi lengan tangan pada posisi lurus sejajar dengan bagian pemasukan sehingga mengurangi kelelahan. 


\section{Mekanisme Pemarutan}

Bongkahan batang sagu dimasukkan melalui bagian pemasukan (hopper), kemudian dorong menuju silinder parut dan hasil parutan akan keluar bada bagian pengeluaran. Terdapat dua mekanisme gaya pada proses pemarutan yaitu gaya dorong oleh operator dan gaya tarik karena pengaruh putaran silinder parut berlawanan jarum jam. Mekanisme pemarutan dapat dilihat pada Gambar 5.

\section{Analisis Daya Pemarutan}

Daya pemarutan dapat dianalisis berdasarkan kebutuhan torsi pemarutan. Darma (2000) melaporkan bahwa kebutuhan torsi pemarutan maksimum untuk pemarutan empulur sagu adalah 10,76 Nm dengan menggunakan silinder parut yang berdiameter $12 \mathrm{~cm}$. Hubungan antara daya putar (torsi) yang bekerja dan gaya yang dapat dipindahkan (transmitted force) dirumuskan seperti Persamaan 1.

$$
T=\frac{d}{2} x F
$$

Sehingga gaya pemarutan (Persamaan 2):

$$
\begin{aligned}
& F=\frac{d}{2} x T \\
& F=\frac{d}{0,12} \times 10,76 \\
& F=179,33 N
\end{aligned}
$$

Kebutuhan daya pada diameter silinder $20 \mathrm{~cm}$ dapat dihitung menggunakan Persamaan 3.

$P=2 \mu R\left(\frac{n}{60}\right) x F$

$P=2 \times 3,14 \times 0,1\left(\frac{1400}{60}\right) \times 179,33 N$

$P=2627,78 W$

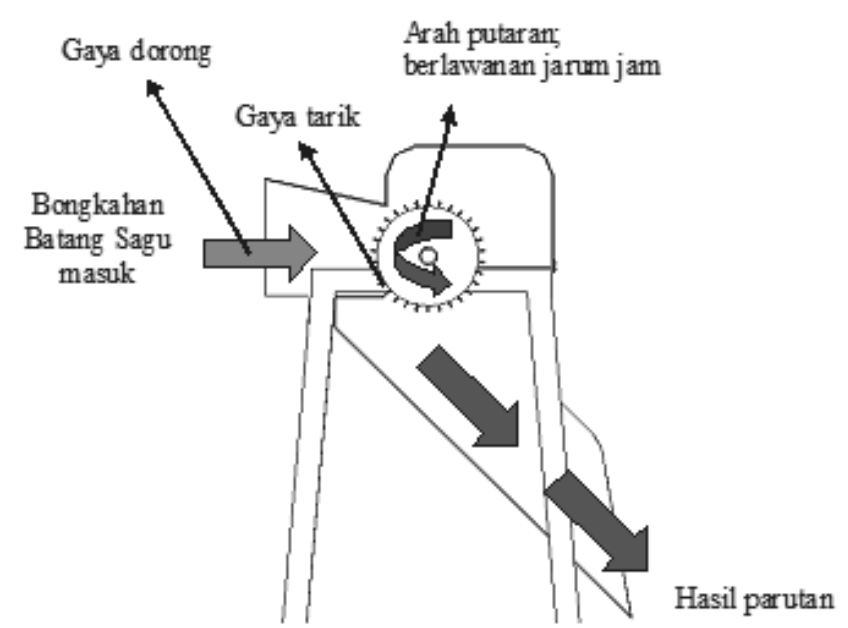

Gambar 5. Makanisme pemarutan
Didapatkan $\mathrm{P}=2,63 \mathrm{KW}$, atau setara dengan 3,52 HP. Bila efisiensi motor bensin yang digunakan adalah 70\%, maka daya yang dibutuhkan adalah 5 HP.

\section{Pembuatan Mesin Pemarut Sagu}

Pembuatan konstruksi mesin mengacu pada hasil analisis desain dan gambar teknik yang telah dibuat sebelumnya. Setiap komponen dibuat dan dirangkai menjadi satu kesatuan. Pembuatan komponen mesin diprioritaskan pada pembuatan silinder pemarut, karena silinder pemarut merupakan komponen utama dari mesin pemarut dan proses pembuatan yang membutuhkan waktu paling lama dan memerlukan ketelitian.

\section{Uji Fungsional}

Uji fungsional dilakukan untuk mengetahui apakah setiap bagian alat dapat berfungsi dengan baik atau tidak. Pengujian ini dilakukan setelah alat pemarut sagu telah selesai proses pembuatannya. Bila semua komponen berfungsi dengan baik dan bekerja sesuai dengan yang diharapkan maka selanjutnya dilakukan uji kinerja, sedangkan bila terdapat komponen yang bekerja tidak sesuai dengan yang diharapkan maka dilakukan modifikasi.

\section{Uji Kinerja}

Untuk memastikan mesin pemarut sagu bekerja sesuai dengan tujuan dan kriteria yang ingin dicapai maka uji kinerja dilakukan sebanyak 10 kali ulangan. Bahan yang digunakan pada uji kinerja ini adalah bongkahan batang sagu seperti dapat dilihat pada Gambar 6. Pemotongan batang sagu menjadi bongkahan bertujuan untuk mempermudah proses masuk ke bagian silinder parut. Sebelum diparut bongkahan batang sagu tersebut ditimbang menggunakan timbangan digital.

Setelah diparut empulur sagu hasil parutan serta batang sagu yang tidak terparut dimasukkan ke dalam kantong plastik, diberi label kode dan ditimbang sesuai dengan urutan pemarutan. Adapun beberapa parameter yang diukur selama proses pengujian terdiri atas:

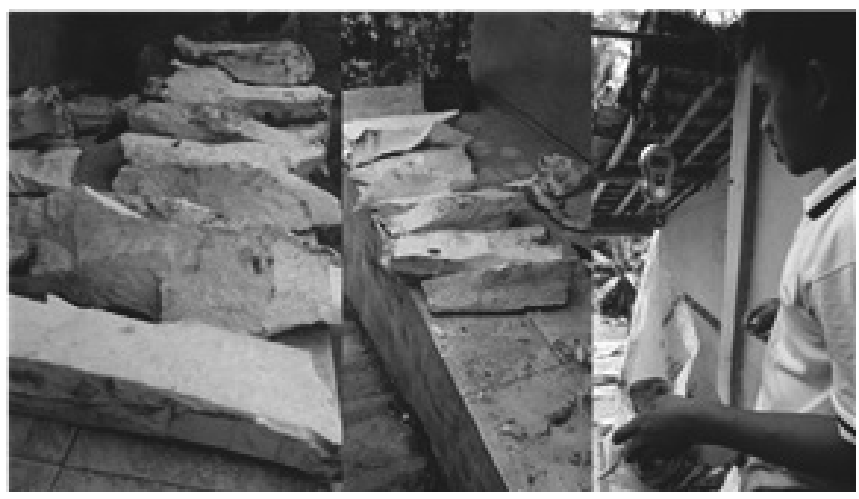

Gambar 6. Bongkahan batang sagu 


\section{a) Kapasitas efektif}

Kapasitas efektif dihitung dengan cara mencatat lansung hasil parutan dalam selang waktu tertentu. Jika kapasitas efektif dilambangkan dengan $\mathrm{C}_{\mathrm{e}}$ dan sagu hasil parutan adalah $\mathrm{S}_{\mathrm{p}}$ dalam selang waktu (t) maka kapasitas efektif pemarutan (Persamaan 4).

$C_{e}=S_{p} / t$

Dimana:

$\mathrm{C}_{\mathrm{e}}=$ kapasitas efektif $(\mathrm{kg} / \mathrm{jam})$

$\mathrm{S}_{\mathrm{p}}=$ empulur sagu hasil parutan $(\mathrm{kg})$

$\mathrm{t}=$ waktu pemarutan (jam)

\section{b) Kehilangan hasil parutan}

Kehilangan hasil parutan dapat diketahui dengan cara menghitung berat sagu sebelum diparut dengan hasil parutan. Jika berat sagu sebelum diparut adalah $\mathrm{B}_{\mathrm{a}}$ empulur sagu hasil parutan $\left(\mathrm{S}_{\mathrm{p}}\right)$ maka kehilangan hasil pemarutan $\left(\mathrm{K}_{\mathrm{p}}\right)$ seperti Persamaan 5.

$K_{p}=\frac{B_{a}-S_{p}}{B_{a}} \times 100 \%$

Dimana:

$\mathrm{Kp}=$ kehilangan hasil parutan $(\%)$

$\mathrm{Ba}=$ berat awal bongkahan batang sagu $(\mathrm{kg})$

\section{c) Efisiensi pemarutan}

Efisiensi pemarutan diperoleh dengan cara membandingkan sagu hasil parutan $\left(\mathrm{S}_{\mathrm{p}}\right)$ dengan sagu yang akan diparut sagu $\left(\mathrm{B}_{\mathrm{a}}\right)$ seperti pada Persamaan 6.

$E_{f}=\frac{s_{p}}{B_{a}} \times 100 \%$

Dimana: $\mathrm{Ef}=$ Efisiensi pemarutan $(\%)$

\section{d) Rendemen pati}

Rendemen pati didapatkan dari hasil ektraksi empulur sagu hasil parutan secara manual. Pada mulanya empulur sagu dimasukkan ke dalam ember, diberi air, dan diaduk sehingga terjadi proses kelarutan pati ke dalam air. Setelah beberapa saat empulur sagu dalam air tersebut diperas secara manual menggunakan saringan.

Proses pencampuran dengan air, pengadukan dan pemerasan dilakukan sampai dua kali ulangan. Air hasil perasan didiamkan selama 12 jam maka pati sagu akan mengendap di bagian bawah ember dan air berada pada bagian atas. Pati sagu yang mengendap tersebut kemudian ditimbang. Rendemen pati dihitung berdasarkan Persamaan 7 dan 8 .

$$
\begin{aligned}
& R_{s}=\frac{T_{s}}{S_{p}} x 100 \% \\
& R_{S}=\frac{T_{s}}{B_{a}} x 100 \%
\end{aligned}
$$

Dimana:

Rs $=$ Rendemen pati $(\%)$

$\mathrm{Ts}=$ Berat pati basah $(\mathrm{kg})$

$\mathrm{S}_{\mathrm{p}}=$ Berat empulur hasil parutan $(\mathrm{kg})$

$\mathrm{Ba}=$ berat awal bongkahan batang sagu $(\mathrm{kg})$

\section{HASIL DAN PEMBAHASAN}

\section{Kontruksi Mesin Pemarut Sagu Tipe TPB01}

Konstruksi mesin pemarut sagu pada penelitian ini dapat dilihat pada Gambar 7. Mesin pemarut sagu tersebut digerakkan oleh motor bensin 5,5 HP dengan sistem transmisi belt dan pulley. Pulley yang terhubung pada poros motor penggerak berdiameter $7,2 \mathrm{~cm}$, pulley yang terhubung pada poros silinder parut berdiameter $15 \mathrm{~cm}$ dan v-bel yang digunakan adalah tipe B65. Konstruksi penutup silinder parut dan bagian pengeluaran serta bagian pemasukan terbuat dari plat stainless steel 304 (SS 304) dengan ketebalan 2 $\mathrm{mm}$, rangka mesin terbuat dari hollow SS 4 x $4 \mathrm{~cm}$, mata parut terbuat dari kawat SS ø $3 \mathrm{~mm}$ dan panjang $15 \mathrm{~mm}$ yang dipasangkan dengan jarak $1 \mathrm{~cm}$ pada silinder parut berdiameter $17 \mathrm{~cm}$ dan panjang $40 \mathrm{~cm}$ proses pemasangan mata parut ke silinder parut menggunkan las argon. Secara keseluruhan mesin pemarut sagu ini memiliki tinggi $120 \mathrm{~cm}$, lebar $60 \mathrm{~cm}$ dan panjang $65 \mathrm{~cm}$.

Pengoperasian mesin pemarut sagu tersebut diawali dengan menghidupkan dan mengatur gas motor penggerak. Kemudian operator memasukkan bongkahan sagu melalui bagian pemasukan dan mendorongnya menggunakan bongkahan sagu yang lain.

\section{Uji Kinerja Mesin Pemarut Sagu Tipe TPB01}

Uji kinerja dilakukan untuk mengetahui apakah alat yang dibuat telah memenuhi tujuan dan kriteria yang ingin dicapai atau tidak. Selain itu adalah untuk keberhasilan suatu proses desain dari mesin. Uji kinerja mesin pemarut sagu dillakukan pada putaran silinder parut sebesar 1400 RPM. Beberapa parameter yang diukur pada pengujian kinerja meliputi:

\section{Kapasitas Efektif}

Kapasitas efektif menunjukkan kemampuan mesin dalam melakukan proses pengolahan produk per satuan waktu. Kapasitas efektif mesin pemarut sagu dihitung berdasarkan berat empulur hasil parutan persatuan waktu. Data hasil pengujian dapat dilihat pada Tabel 2. 


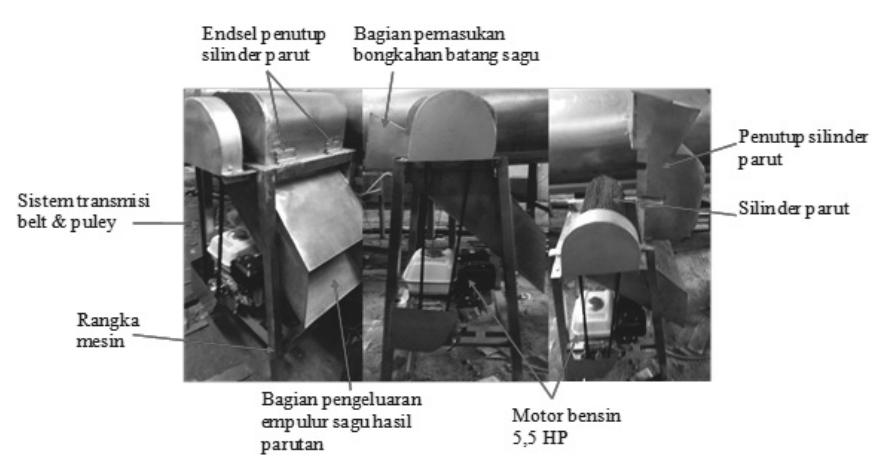

Gambar 7. Konstruksi mesin pemarut sagu tipe silinder dan bagian-bagiannya

Tabel 2. Kapasitas efektif pada putaran silinder parut 1400 rpm

\begin{tabular}{cllll}
\hline Ulangan & $\begin{array}{l}\text { Berat } \\
\text { awal }\end{array}$ & $\begin{array}{l}\text { Waktu } \\
\text { pemarutan }\end{array}$ & $\begin{array}{l}\text { Berat empulur } \\
\text { hasil parutan }\end{array}$ & $\begin{array}{l}\text { Kapasitas } \\
\text { efektif }\end{array}$ \\
\cline { 2 - 5 }$(\mathrm{Kg})$ & $($ Detik $)$ & $(\mathrm{Kg})$ & $(\mathrm{Kg} / \mathrm{jam})$ \\
\hline 1 & 4,01 & 23,82 & 3,61 & 545,59 \\
2 & 3,10 & 18,29 & 2,67 & 525,53 \\
3 & 2,72 & 15,67 & 2,69 & 618,00 \\
4 & 2,86 & 18,06 & 2,75 & 548,17 \\
5 & 2,95 & 12,88 & 2,78 & 777,02 \\
6 & 2,78 & 15,00 & 2,65 & 636,00 \\
7 & 3,02 & 15,00 & 2,78 & 667,20 \\
8 & 4,53 & 22,35 & 4,20 & 676,51 \\
9 & 2,70 & 11,15 & 2,48 & 800,72 \\
10 & 2,66 & 13,08 & 2,54 & 699,08 \\
Jumlah total & 31,33 & 165,30 & 29,15 & 6493,82 \\
Rata - rata & 3,13 & 16,53 & 2,92 & 649,38 \\
\hline
\end{tabular}

Berdasarkan Tabel 2 dapat dilihat bahwa rata-rata kapasitas efektif mesin pemarut sagu hasil rancangan dari 10 (sepuluh) kali ulangan pada putaran silinder parut $1400 \mathrm{rpm}$ adalah sebesar 649,38 kg per jam per orang. Berat awal bahan yang diparut dari tiap ulangan berbeda-beda. Hal ini karena proses pengujian mesin mangacu pada kondisi nyata proses pemarutan sagu yang dilakukan oleh kelompok masyarakat di Papua, dimana empulur sagu dipotong dengan ukuran yang tidak seragam. Kapasitas yang dihasilkan tersebut lebih besar jika dibandingkan dengan mesin pemarut yang telah dibuat dan diteliti sebelumnya seperti dapat dilihat pada Tabel 3.

Berdasarkan Tabel 3 menunjukkan bahwa salah satu faktor yang mempengaruhi kapasitas selain putaran silinder parut (RPM) adalah tipe mata gigi dan dimensi silinder parut. Dimensi silinder parut yang dibuat juga akan mempengaruhi dimensi konstruksi mesin secara keseluruhan dan banyaknya bongkahan batang sagu yang dapat diparut.
Tabel 3. Tipe mata parut dan kapasitas mesin pemarut sagu

\begin{tabular}{|c|c|c|c|c|}
\hline No & Tipe & Dimensi silinder parut & $\begin{array}{l}\text { Kap a s itas } \\
(\mathrm{Kg} / \mathrm{jam})\end{array}$ & Peneliti \\
\hline \multirow[t]{2}{*}{1} & Silinder bergigi & Panjang $20 \mathrm{~cm}, \varnothing 15 \mathrm{~cm}$ & 418 & Darma, 2011 \\
\hline & & Panjang $20 \mathrm{~cm}, \varnothing 15 \mathrm{~cm}$ & $350-450$ & $\begin{array}{l}\text { Kurniawan } \\
\text { dkk., } 2012\end{array}$ \\
\hline 2 & $\begin{array}{l}\text { Silinder jarum } \\
\text { seperti pemarut } \\
\text { kelapa }\end{array}$ & Panjang $40 \mathrm{~cm}, \varnothing 26 \mathrm{~cm}$ & 268,43 & Irawan, 2009 \\
\hline 3 & Piringan datar & Panjang $12 \mathrm{~cm}, \varnothing 12 \mathrm{~cm}$ & $86-132$ & $\begin{array}{l}\text { Payung, 2007; } \\
\text { Payung, } 2013\end{array}$ \\
\hline 4 & Silinder bergigi & Panjang $37 \mathrm{~cm}, \varnothing 20 \mathrm{~cm}$ & $\begin{array}{l}299,13 \pm \\
20,95\end{array}$ & $\begin{array}{l}\text { Santoso dkk., } \\
2015\end{array}$ \\
\hline 5 & Silinder bergigi & Panjang $20 \mathrm{~cm}, \varnothing 10 \mathrm{~cm}$ & 422,13 & Juwita, 2014 \\
\hline
\end{tabular}

Putaran silinder parut akan mempengaruhi kapasitas mesin, pada putaran rendah akan menghasilkan kapasitas pemarutan yang rendah namun pada putaran silinder parut yang tinggi selain menghasilkan getaran yang tinggi juga akan menghasilkan kapasitas pemarutan yang rendah. Uji coba pada putaran silinder parut $1600 \mathrm{rpm}$ menghasilkan kapasitas efektif sebesar 488,50 kg/jam, rendahnya kapasitas tersebut disebabkan karena banyaknya empulur hasil parutan yang hilang.

\section{Kehilangan Hasil Parutan}

Kehilangan hasil parutan adalah banyaknya massa empulur sagu yang hilang sewaktu pemarutan. Kehilangan hasil parutan dapat diperoleh dari selisih antara berat awal empulur dan akhir hasil parutan. Kehilangan hasil parutan dapat dilihat pada Tabel 4. Rata-rata kehilangan hasil parutan dari 10 kali ulangan pada putaran silinder parut $1400 \mathrm{rpm}$ yaitu sebesar 6,71\%. Hal ini disebabkan oleh

Table 4. Kehilangan hasil parutan pada putaran silinder parut $1400 \mathrm{rpm}$

\begin{tabular}{ccccccc}
\hline Ulangan & $\begin{array}{c}\text { Berat } \\
\text { awal }\end{array}$ & $\begin{array}{c}\text { Berat empulur } \\
\text { hasil parutan }\end{array}$ & Kehilangan & \multicolumn{2}{c}{$\begin{array}{c}\text { Berat yang } \\
\text { tidak terparut }\end{array}$} \\
\hline & $(\mathrm{Kg})$ & $(\mathrm{Kg})$ & $(\mathrm{Kg})$ & $\%$ & $(\mathrm{Kg})$ & $\%$ \\
1 & 4,01 & 3,61 & 0,40 & 9,98 & 0,16 & 3,99 \\
3 & 3,10 & 2,67 & 0,43 & 13,87 & 0,07 & 2,26 \\
4 & 2,72 & 2,69 & 0,03 & 1,10 & 0,15 & 5,51 \\
5 & 2,86 & 2,75 & 0,11 & 3,85 & 0,12 & 4,20 \\
6 & 2,95 & 2,78 & 0,17 & 5,76 & 0,18 & 6,10 \\
7 & 2,78 & 2,65 & 0,13 & 4,68 & 0,17 & 6,12 \\
8 & 3,02 & 2,78 & 0,24 & 7,95 & 0,17 & 5,63 \\
9 & 4,53 & 4,20 & 0,33 & 7,28 & 0,23 & 5,08 \\
10 & 2,70 & 2,48 & 0,22 & 8,15 & 0,08 & 2,96 \\
Jumlah total & 31,33 & 29,15 & 0,12 & 4,51 & 0,1 & 3,76 \\
Rata - rata & 3,13 & 2,92 & 2,18 & 67,13 & 1,43 & 45,60 \\
\hline
\end{tabular}




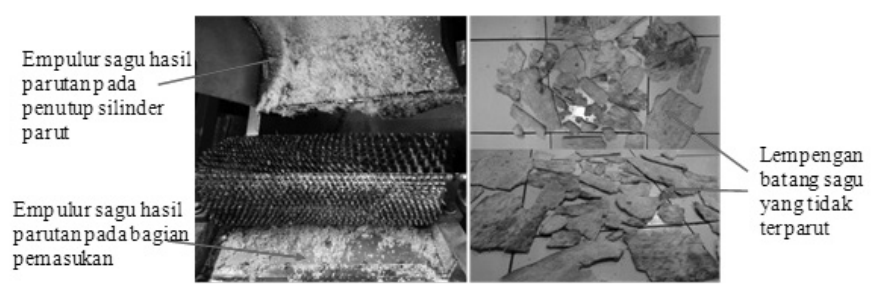

(a)

(b)

Gambar 8. Kehilangan hasil parutan: (a) Tertinggal pada penutup silinder parut, (b) Batang sagu yang tidak terparut

sebagian empulur hasil masih tertinggal dan menempel pada bagian komponen mesin seperti penutup silinder parut dan pendorong empulur seperti dapat dilihat pada Gambar 6(a) dan sebagian bahan lagi terdapat dan batang sagu yang tidak terparut seperti yang dapat dilihat pada Gambar 6(b).

Berdasarkan pengukuran dari 10 (sepuluh) kali ulangan, batang sagu yang tidak terparut sebesar 4,56\% dan empulur sagu hasil parutan yang tertinggal pada penutup silinder sebesar 2,39\%. Batang sagu yang tidak terparut berbentuk lempengan dan berukuran lebar/panjang berkisar antara 5-15 cm dengan tebal $5 \mathrm{~mm}$. Lempengan batang sagu yang tidak terparut disebabkan karena terdapat selisih atau celah antara mata parut dan bagian pemasukan. Karena adanya proses tarikan dari silinder parut yang berputar menyebabkan pada bagian akhir proses pemarutan meninggalkan lempengan batang sagu yang tidak terparut.

Kecepatan putar silinder parut yang lebih tinggi (1600 rpm) akan menyebabkan kehilangan hasil parutan yang lebih besar. Berdasarkan pengukuran bagian empukur yang tertinggal pada komponen mesin sebesar 9,66\% dan batang yang tidak terparut adalah sebesar 8,19\%. Hal ini dibuktikan dari hasil penelitian sebelumnya pada kecepatan putar silinder $1200 \mathrm{rpm}$ di dapatkan kehilangan hasil parutan sebesar 4,2\% (Irawan, 2009). Empulur sagu hasil parutan yang tertinggal pada silinder parut disebabkan proses lemparan dari silinder parut yang berputar selama proses pemarutan. Namun demikian, empulur sagu yang tertinggal pada komponen mesin dapat diambil dan diolah lebih lanjut setelah selesai proses pemarutan atau pada saat pembersihan mesin. Sedangkan batang sagu yang tidak terparut akan mengurangi rendemen pati sagu yang dihasilkan.

\section{Efisiensi Pemarutan}

Efisiensi pemarutan dapat diperoleh dengan cara membandingkan antara massa sagu hasil parutan dengan empulur sagu yang akan diparut (Persamaan 3). Dengan menggunakan persamaan tersebut didapat rata-rata efisiensi pemarutan sebesar 93,04\%. Pada penelitian sebelumnya dengan model mata parut yang sama dan jarak mata parut $10 \mathrm{~mm}$ didapatkan efesiensi pemarutan sebesar 90,83\% (Payung, 2007) sedangkan efesiensi pemarutan pada mata parut berbentuk jarum yaitu sebesar 95,78\% (Irawan, 2009). Efisiensi pemarutan ini sangat dipengaruhi oleh faktor kehilangan hasil parutan dan bagian empulur yang tidak terparut. Semakin besar kehilangan hasil parutan dan batang sagu yang tidak terparut, maka efisiensi mesin akan menurun.

\section{Rendemen Pati}

Rendemen pati dihitung dengan menggunakan Persamaan 4 dan 5. Hasil pengukuran rendemen pati dapat dilihat pada Tabel 5 .

Tabel 5. Rendemen pati

\begin{tabular}{clllll}
\hline No & $\begin{array}{l}\text { Berat } \\
\text { awal }\end{array}$ & $\begin{array}{l}\text { Berat empulur } \\
\text { hasil parutan }\end{array}$ & $\begin{array}{l}\text { Berat } \\
\text { tepung } \\
\text { sagu }\end{array}$ & $\begin{array}{l}\text { Rendemen pati } \\
\text { berdasarkan berat } \\
\text { bongkahan }\end{array}$ & $\begin{array}{l}\text { Rendemen } \\
\text { berdasarkan } \\
\text { hasil parutan }\end{array}$ \\
\hline & $(\mathrm{Kg})$ & $(\mathrm{Kg})$ & $(\mathrm{Kg})$ & $(\%)$ & $(\%)$ \\
1 & 5,36 & 5,02 & 0,48 & 8,86 & 9,46 \\
2 & 6,73 & 6,3 & 0,89 & 13,22 & 14,13 \\
3 & 2,86 & 2,75 & 0,60 & 20,98 & 21,82 \\
Rata-rata & 4,98 & 4,69 & 0,66 & 14,36 & 15,14 \\
\hline
\end{tabular}

Tabel 4 menunjukkan bahwa hasil pengujian rendemen pati berdasarkan pengukuran dari berat awal empulur sebelum pemarutan adalah $14,36 \%$, sedangkan dihitung berdasarkan berat empulur sagu setelah pemarutan adalah $15,14 \%$. Rendemen pati sagu hasil pengujian tersebut jauh lebih rendah dibandingkan dengan hasil penelitian Darma (2011) yaitu sebesar 38,09\% dan Hermanto dkk. (2011) yaitu sebesar $24,34 \%$. Hal ini karena rendemen pati yang dihasilkan sangat dipengaruhi oleh berbagai faktor diantaranya adalah varietas atau jenis tanaman sagu (Limbongan, 2007), umur tanaman sagu (Maherawati dkk., 2011), tinggi tanaman sagu (Darma dkk., 2010). Menurut Bintoro dkk. (2010) kandungan pati optimal terdapat pada batang sagu menjelang munculnya calon bunga dimana pada masa itu tanaman sagu telah mencapai masak fisiologis. Setelah bunga muncul pati sagu akan menurun secara signifikan. Oleh karena itu, rendemen pati sagu sebagaimana tertera pada Tabel 4 tidak dapat dibandingkan dengan rendemen pati dari hasil penelitian dan pengujian mesin pemarut sagu yang lain karena sumber bahan baku yang berbeda.

\section{Respon Kepuasan Pengguna}

Mesin pemarut sagu yang telah diuji kinerja selanjutnya di-packing dan dikirim ke pengguna di Kabupaten Teluk Bintuni, Provinsi Papua Barat. Respon dari pengguna berkenaan dengan desain mesin sangat diperlukan untuk 
perbaikan mesin sehingga menjadi lebih baik. Berdasarkan komunikasi yang dilakukan, diperoleh informasi bahwa pengguna mengeluhkan kesulitan mengencangkan sabuk $v$-belt yang menghubungkan antara puli poros silinder parut dan puli motor penggerak. Karena posisi motor penggerak terletak tapat di bagian bawah silinder parut sehingga sulit untuk digeser akibat ruang yang terbatas. Selain itu, pengguna mengeluhkan adanya kontak mata parut dengan landasan pada bagian pemasukan batang sagu dan banyaknya bagian batang sagu yang tidak terparut sempurna.

\section{KESIMPULAN}

Mesin pemarut sagu hasil modifikasi memiliki dimensi tinggi $120 \mathrm{~cm}$, lebar $60 \mathrm{~cm}$, dan panjang $65 \mathrm{~cm}$. Menggunakan tenaga penggerak motor bensin 5,5 HP dengan sistem transmisi belt dan pulley. Seluruh konstruksi mesin terbuat dari stainless steel. Pada putaran silinder parut 1400 RPM, mesin pemarut sagu hasil desain memiliki kapasitas sebesar 649,38 kg/ jam, tingkat kehilangan empulur sagu sebesar 6,71\% berupa batang yang tidak terparut sebesar $4,56 \%$ dan parutan yang tertinggal pada mesin sebesar $2,39 \%$.

\section{UCAPAN TERIMA KASIH}

Ucapan terima kasih diberikan kepada Dinas Pertanian Kabupaten Teluk Bintuni, Provinsi Papua Barat yang telah memberikan kepercayaan kepada penulis untuk membantu masyarakat Papua melaui penelitian dan pengembangan mesin pemarut sagu.

\section{DAFTAR PUSTAKA}

Anonim. (2016) Rekap Data Antropometri Indonesia. http://antropometriindonesia.org/index.php/detail/ artikel/4/10/data_antropometri [17 Agustus 2016].

Bintoro, M.H., Purwanto, M.Y.J. dan Amarillis, S. (2010). Sagu di Lahan Gambut. IPB Press, Bogor.

Bintoro, MH. (2008). Bercocok Tanam Sagu. IPB Press, Bogor.

Darma, Herodian, S. dan Suawtawa, I.N. (2000). Desain dan analisis kebutuhan tenaga pada alat pemarut sagu tipe silinde. Prosiding Seminar Nasional Teknik Pertanian. 11-12 Juli 2000. Bogor. Hal. 164-171

Darma, Istalaksana dan Andreas. (2010). Prototipe alat pengekstrak pati sagu tipe mixer rotary blade bertenaga motor bakar. Agritech 30(4): 204-211. Doi: doi. org/10.22146/agritech.9709.

Darma (2011). Variant-I mesin pemarut sagu tipe silinder bertenaga motor bakar. Jurnal Agrotek 2(3): 80-88.
Hermanto, Ansharullah, Nuwiyah, A. dan Muhidin. (2011). Perbedaan teknik pemarutan dan pengaruhnya terhadap peningkatan rendemen dan mutu tepung sagu. Jurnal Agriplus 21(1): 30-35.

Irawan, P. (2009). Rancangan dan Uji Teknis Alat Pemarut Sagu Tipe Silinder. Skripsi. Fakultas Teknologi Pertanian. Institut Pertanian Bogor, Bogor.

Juwita, I. (2014). Analisis Tekno Ekonomi Terhadap Pemarut Sagu Mekanis (Studi Kasus Pabrik Gilingan Sagu Alue Jareng Kabupaten Pidie, Aceh). Skripsi. Fakultas Pertanian. Universitas Syah Kuala, Aceh.

Kurniawan, A., Darma dan Istalaksana, P. (2012). Pengembangan agroindustri pengolahan sagu di Provinsi Papua untuk mendukung ketahanan dan diversifikasi pangan. Prosiding Seminar Insentif Riset Sistem Inovasi Nasional. 29-30 November 2012. Bandung. Hal. 214-216.

Limbongan J. (2007). Morfologi beberapa jenis sagu potensial di Papua. Jurnal Litbang Pertanian 26(1): 16-24.

Maherawati, Lestari, B.R. dan Haryadi (2011). Karakteristik pati dari batang sagu Kalimantan Barat pada tahap pertumbuhan yang berbeda. Agritech 31(1): 9-13. Doi: doi.org/10.22146/agritech.9720.

Payung, P. (2007). Rancang Bangun dan Uji Kinerja Alat Penghancur Mekanis Empulur Sagu (Metroxylon sp.) Tipe Piringan Datar. Tesis. Fakultas Teknologi Pertanian. Universitas Gadjah Mada, Yogyakarta.

Payung, P. (2013). Kajian diameter puli dan jarak mata gigi parut sagu (Metroxylon sp.) Mekanis tipe piringan datar terhadap daya pemarutan, kapasitas dan rendemen pati. Jurnal Informasi Sains dan Teknologi 5(1): 7-14.

Santoso, Mislaini, R. dan Putra, R. (2015). Rancang bangun alat pencacah dan pemarut sagu dengan sumber pengerak motor listrik. Prosiding Seminar Agroindustri dan Lokakarya Nasional FKPT - TPI. 2-3 September 2015. Madura. Hal. C13-C32.

Thoriq, A. dan Herodian, S. (2015). Perkembangan alat dan mesin pengolahan sagu di pulau papua dan strategi pengembangannya. Prosiding Seminar Nasianal Informatika Pertanian. 12-13 November 2015. Bandung. Hal. 70-83.

Unit Percepatan Pembangunan Provinsi Papua dan Provinsi Papua Barat (UP4B). (2013). Master Plan Pengembangan Sagu Sebagai Komoditas Unggulan Provinsi Papua dan Provinsi Papua Barat. Laporan Kajian. UP4B. Jakarta. 